\title{
gr ofia.
}

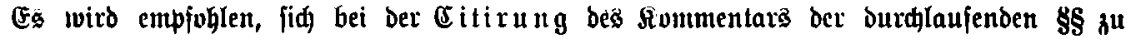

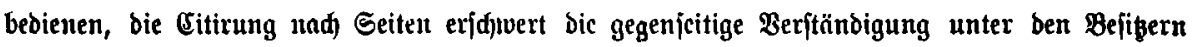
ber verfdiebenen Iruflagen. 